\title{
Institutional Factors Influencing the Decision to Take Financial Credits among Small Holder Coffee Farmers in Rwanda
}

\author{
Iyakare Super Mpirwa ${ }^{1}$, David Mwehia Mburu ${ }^{2}$, Patrick Mulyungi ${ }^{2}$, Ntaganira Eric $^{3}$, \\ Nsengiyumva Aimable ${ }^{4}$ \\ ${ }^{1}$ Postgraduate student, Jomo Kenyatta University of Agriculture and Technology \\ iyampirwas@gmail.com \\ ${ }^{2}$ Senior Lecturer,Jomo Kenyatta University of Agriculture and Technology \\ ${ }^{3}$ Assistant Lecturer Jomo Kenyatta University of Agriculture and Technology, Kigali-Rwanda \\ nyamurasaeric@yahoo.com \\ ${ }^{4}$ The Secretary to the Scientific committee, Rwanda Agriculture Board and the Assistant Lecturer Jomo \\ Kenyatta University of Agriculture and Technology, Kigali-Rwanda \\ bainse1@gmail.com

\begin{abstract}
:
Though, a lot of emphasis has been put to decentralize financial institutions to offer agricultural credit, access to credit in many rural households in Rwanda remains limited, so far no study done in the study area on institutional factors influencing the decision to take credit. This study investigated the institutional factors influencing the decision to take credit among smallholder coffee farmers in Gisagara District, Southern Province of Rwanda. A Multi stage sampling techniques was employed to select respondents. Primary data were drawn from 222 smallholder farmers using structured questionnaires.Binary logistic regression was employed to estimate the data. The results indicated that the institutional factors which influenced access to credit were cooperative membership, extension services, information on credit use, fear take risk and distance to coffee washing station. Based on the findings of the study, recommended that in order to increase access to use agricultural credit there is need to focus in organizing coffee producers in cooperatives, strengthen the current strategies of extension, education and infrastructural services particularly for road transport.
\end{abstract}

Key words: Farmer savings, logit model, Smallholder coffee farmers, Gisagara District, Rwanda

\section{Introduction}

The access to financial services by smallholder farmers is normally seen as one of the constraints limiting their benefits from credit facilities (Wiggins, S., 2009). The author classified the challenges to finance services into five main categories. The first category relates to socioeconomic constraints that limit both the supply of and the demand for financial services. The second deals with weaknesses in the macroeconomic environment that deters large segments of the population from using the services provided by the formal financial system. The third identifies characteristics in the operations of the formal financial system that impede the adequate provision of financial services to households and firms. The fourth focuses on environmental deficiencies, with emphasis on the quality of the legal framework and the governability of countries. The fifth category identifies regulations that tend to distort the provision of financial services.

The financial exclusion of smallholder farmers from credit is normally part of a wider social exclusion, which involves income, type of employment, education level, etc. In general, the countries with greater access to social services and a better quality of life are the ones which have developed a stronger financial culture in which the use of financial services through formal markets becomes indispensable. The Poor rural households in developing countries lack adequate access to credit and many development professionals believe that this lack of credit has negative consequences for poor people's agricultural productivity, food security, health, and overall household welfare (Girma, M. and Abebaw, D., 2015).This lack of credit is due to the fact that the smallholders in Rwanda are characterized by landholdings of about one hectare in average and cannot grow enough food 
to feed them. Because land is scarce, these smallholders can climb out of poverty only by farming more productively and diversifying into non-agricultural activities. In Rwanda agriculture is the main stay of the majority of the population where over $80 \%$ of the population survive by farming and livestock rearing (Bhattacharjee and Rajeev, 2010). However, among other things, lack of finance is one of the fundamental problems impeding production, productivity and income of the rural and urban households. Coffee farming in Rwanda is an important sector that highly contributes to the economy in terms of employment and income especially for the smallholder farmers in rural areas and for the Country as well (Mutandwa et al., 2009). The National Agricultural and Exports Board reported the coffee produced since 2012(19,955tonesofgreen coffee), 2013 (18,346 tones of green coffee), 2014(16,572 tons of green coffee), 2015(18,839tons of green coffee). Notably, the production levels in coffee fluctuate with years. This fluctuation in production could be associated with various problems for instance land scarcity, low inputs use, lack of trainings on best practices and mainly very limited credit accessibility to

\section{Methodology}

\section{A. Study area}

The study was carried out in Gisagara District in Southern Province of Rwanda. The choice of this study area was due to the fact that Gisagara District is among the districts with a lot coffee plantations and lot of coffee washing stations in Rwanda (NAEB, 2015).

\section{B. Research design}

The design employed cross section survey design with help of self-administration of questionnaires to a sample of smallholder coffee farmers. The study used both primary and secondary data in form of quantitative and qualitative data.

\section{Sampling plan}

In the first stage, 3 out of 13 sectors in the district was purposively selected using different criteria such smallholder farmers that blocks them in maintaining the existing coffee plantations or planting new coffee trees. Only the large farmers are the most trustworthy by financial institutions. The resources allocated to agriculture are remarkably low, for example, the amount of credit allocated to agricultural sector is about $4 \%$ in Rwanda which is much less than the proportional contribution of agriculture to the GDP. Recent research shows that $78 \%$ ofthe coffee farmers were constrained to access credit services while $52 \%$ were excluded from financial services all together.

The lack of collateral to offer has discouraged smallholder farmers from accessing credit (Ali, Deininger, \& Duponchel, 2014).Different authors such as Malimba and Ganesan (2010) have raised the problem of repayment behavior in Credit and Savings Cooperative Societies and Financial Services Consumption Constraints in Rwanda, but none has discussed about determinants of credit accessibility to smallholder farmers. This study identified and filled in the gap on the institutional factors influencing credit accessibility among smallholder coffee farmers in Gisagara District, Rwanda.

as number of individual coffee farmers, coffee cooperatives, coffee washing stations available and financial institutions available in the area. In the second stage, stratified sampling was used to divide the sample of coffee household farmers into strata of credit users and non credit users. In the third stage cluster sampling technique was employed to select equal number of respondents per cell. Finally simple random sampling was used this means every coffee farmer was having equal chances of selection. The list of total household heads in the selected sectors was obtained from the sector office. The Slovene's formula was used to calculate the sample size; at 95\% confidence level (this produced a margin of error of 0.05). The formula used was: $n=N /(1+N$ $\mathrm{e}^{2}$ ). The size of samples was kept proportional to the size of the stratum.

$n=\frac{500}{1+500(\alpha)^{2}}=22$ 
Table 1: Sampling frame

\begin{tabular}{|l|l|c|c|c|c|}
\hline \multirow{2}{*}{ Sectors } & Cells & \multirow{2}{*}{$\begin{array}{c}\text { Total } \\
\text { coffee farmers }\end{array}$} & \multicolumn{2}{|c|}{ Number of sample selected } & Total sample \\
\cline { 4 - 6 } & & 74 & 15 & 22 & 37 \\
\hline \multirow{2}{*}{ Kusha } & Bukinanyana & 102 & 15 & 22 & 37 \\
\cline { 2 - 6 } & Kimana & 89 & 15 & 22 & 37 \\
\hline & Agahabwa & 68 & 15 & 22 & 37 \\
\cline { 2 - 6 } & Rusagara & 98 & 15 & 22 & 37 \\
\hline & Runyinya & 69 & 15 & 22 & 37 \\
\hline Total & Nyabisagara & $\mathbf{5 0 0}$ & $\mathbf{9 0}$ & $\mathbf{1 3 2}$ & $\mathbf{2 2 2}$ \\
\hline
\end{tabular}

\section{Data collection instruments}

Both qualitative and quantitative data was collected from primary and secondary data sources. Primary data was collected using survey questionnaire where as secondary data was through review of reports and publications.

\section{E. Data analysis}

Data were estimated by use of "stata 13 software" and binary logit model was used to determine factors influencing accessibility to credit. The correlations between two different variables were done in order to observe the significance of the dependent and the independent variables.

\section{F. Model applied in the study}

The logistic regression coefficient can be used to estimate odds ratios for each of the independent variables in the model. The logistic regression model (logit model) is applicable to a broader range of research situations than discriminate analysis. The term "logit" refers to the natural logarithm of the odds (log odds) which indicates the probability of falling into one of two categories on some variable of interest(Imbens \& Wooldridge, 2009). The author also asserts that the model shows how a set of predictor (explanatory) variables (X's) are related to a dichotomous response variable $\mathrm{Y}(\ln (\mathrm{Pi} / 1-\mathrm{Pi})$. The dichotomous response variable $\mathrm{Y}=0$ or 1 with $Y=1$ denotes the occurrence of the event of interest while $\mathrm{Y}=0$ denotes otherwise.

The dummy variables, also known as indicators and bound variables, characterize dichotomous responses. In this study, since only two options were available, namely "access to credit" or "no access to credit" a binary model was set up to define $Y=1$ for situation where the farmer accessed credit and $Y=0$ for situations where the farmer did not access credit from either formal or informal credit sources. Both the Logit and Probit models estimate parameters using maximum likelihood method. The Logit model was preferred due to the consistency of parameter estimation associated with the assumption that error term in the equation has a logistic distribution(Apata et al., 2010).Therefore the current study adopts the logit model.

Assuming that Xis a vector of explanatory variables and $p$ is the probability that $\mathrm{Y}=1$, two probabilistic relationships can be considered as follows (Imbens \& Wooldridge, 2009):

$$
\begin{aligned}
& p(Y=1)=\frac{e^{\beta x}}{1+e^{\beta x}} \ldots \ldots \ldots \ldots \text { (1) } \\
& p(Y=0)=1-\frac{e^{\beta x}}{1+e^{\beta x}}=\frac{1}{1+e^{\beta x}}
\end{aligned}
$$

Woodridge (2009) concluded that since Equation (2) is the lower response level, that is, the probability that farmers did not access credit from formal and informal credit source, this will be the probability to be modeled by the logistic procedure by convention. Both equations present the outcome of the logit transformation of the odds ratios which can alternatively be represented as:

$$
\begin{aligned}
& \operatorname{logit}[\theta(x)]=\log \left[\frac{\theta(x)}{1-\theta(x)}\right]=\alpha+\beta_{1} X_{1}+\beta_{2} X_{2} \\
& +\ldots . \beta_{k} X \ldots(3)
\end{aligned}
$$

and thus allowing its estimation as a linear model for which the following definitions apply:

$\theta=$ logit transformation of the odds ratio;

$\alpha=$ the intercept term of the model;

$\beta_{1}=$ the regression coefficient or slope of the individual predictor (or explanatory) variables modeled and $\mathrm{Xi}=$ the explanatory or predictor variables.

The logistic regression in this study can be specified as:

$Y_{i}=\alpha+\beta_{1} X_{1}+\beta_{2} X_{2}+\beta 3 X 3+\beta 4 X 4+\ldots \ldots+\mu_{k \ldots}$

Where, $\mathrm{Yi}=$ the dependent variable defined as the access to credit by smallholder farmers $=1$ and 0 otherwise; $\alpha=$ constant and intercept of the 
equation; $\mathrm{X}_{1}, \mathrm{X}_{2}, \mathrm{X}_{3}, \mathrm{X}_{4}, \ldots \ldots$ are the independent variables for the study and $\mu_{\mathrm{k}}=$ correction error term.

\section{Results and Discussion}

Cooperative membership was statistically significant with the positive on influence of smallholder farmer's access to credit, i.e. farmers who are members of associations/groups are more likely to have access to credit. The implication is that the group membership increases the probability of credit access because participation in group activities and being connected to social systems proved to be positively associated with access to financial services. This implies that an improvement of togetherness and collective actions in the study area lead to a positive contribution towards accessing credit financial services, farmer group plays a crucial role in empowering farmers with farming techniques, knowledge and management skills hence reduces the transaction costs and benefit from collective actions. The results of this study also are in line with the findings of (Lukytawati, 2009).

Another factor that negatively influenced access to credit accessibility was fear to take risk, farmers are risk averse. The possible explanation is that farmers' fear to take credit because it is difficult to repay the loan if the risk appears and they might be penalized based on the previous. This is consistent with the prior expectation of (Yehuala, S., 2008).

Another variable that influenced the use of credit accessibility was extension services and information on credit use. Agricultural extension variable and information on use of agricultural credits for farm households which receive technical advice from agricultural extension agents are more likely to use formal credit. A plausible explanation is that, to the extent that extension programs aim at agricultural intensification through adoption of modern technology such as improved seeds, pesticides and fertilizers, farmers working with extension services demand more financial services to support investments in these technologies. The findings of the study are consistent with(Yehuala,S., 2008).

Another variable that negatively affected the use agricultural credit was distance to coffee washing station. The plausible explanation is that farmers far from coffee washing stations facing location disadvantage in saving farm resources (time, labor) which otherwise would have been spent to access credit and can easily and have more access to information than those who live at more distant locations (Mijena, 2011).

Table 2: Institutional factors influencing decision to access credit

\begin{tabular}{|l|l|l|l|l|}
\hline Access to credit & Coef. & Std. Err. & $Z$ & $\mathrm{Z}>|\mathrm{z}|$ \\
\hline Cooperative membership & 0.05 & 0.02 & 2.44 & $\mathbf{0 . 0 1 7}$ \\
\hline Relationships with financial institutions & 0.21 & 0.48 & 0.45 & 0.656 \\
\hline Delays in credit procedures & 0.24 & 0.94 & -5.12 & 0.79 \\
\hline Fear to take risk & -0.25 & 0.16 & -0.32 & $\mathbf{0 . 0 0 0}$ \\
\hline Information on credit use & 0.65 & 0.41 & 1.58 & $\mathbf{0 . 0 1 4}$ \\
\hline Extension services & 0.01 & 0.00 & 2.92 & $\mathbf{0 . 0 0 4}$ \\
\hline Trainings in good agricultural practice & -0.01 & 0.47 & -0.03 & 0.977 \\
\hline Trainings in integrated Pest Management & -0.31 & 0.44 & -0.69 & 0.489 \\
\hline Trainings in Soil erosion control & 0.26 & 0.46 & 0.57 & 0.568 \\
\hline Trainings in Record keeping & -1.01 & 1.44 & -0.71 & 0.48 \\
\hline Distance to nearest road & 0.01 & 0.01 & 0.67 & 0.506 \\
\hline Distance to market & 0.00 & 0.01 & -0.68 & 0.499 \\
\hline Distance to financial institution & 0.00 & 0.01 & -0.26 & 0.797 \\
\hline Distance to coffee washing station & -0.00 & 0.02 & -1.99 & $\mathbf{0 . 0 4 9} *$ \\
\hline Distance to coffee farm plantation & 0.00 & 0.02 & -0.17 & 0.866 \\
\hline Distance to extension agents & -0.01 & 0.01 & -0.88 & 0.379 \\
\hline Constant & $\mathbf{5 . 2 4}$ & $\mathbf{9 . 4 0}$ & $\mathbf{0 . 5 6}$ & $\mathbf{0 . 5 7 7}$ \\
\hline
\end{tabular}

Number of obs $=222$, LR chi2 $(6)=5.25$, Prob $>$ chi2 $=0.5122$,

Pseudo R2 $=0.018$, Log likelihood $=-142.98528$ 


\section{Conclusion and Recommendations}

The study concluded that institutional factors such as cooperative membership, extension services, and information on credit use, fear take risk and distance to coffee washing station influenced uptake of agriculture credit thus the study recommends:

Therefore the study recommends that, to increase access to use of credit, policy makers and stakeholders in Rwanda should mobilize and sensitize smallholder coffee producers to join coffee cooperatives.

There is need for Government efforts and private sector to through provision of extension services for purposes of training and information about importance of using agricultural credits through increasing the numbers of extension worker providers to reduce the farmers' extension worker ratio.

The study recommends the Ministry of Agriculture and Animal Resources in Rwanda and related stakeholders to emphasize on infrastructural services particularly for road transport through construction of feeder roads as way to enhance participation of coffee growers in coffee production.

The study recommends policy makers and implementers in Rwanda to use policies geared towards the development of effective training programs through insurance to mitigate the risks in farming, financial literacy programs to familiarize smallholder farmers with the skills required to effectively understand, assess and utilize credit financial services to enhance their agricultural activity.

This study focused on institutional factors influencing access to credit facilities ,there is a need to conduct more studies on factors like behavioral, social-economic that influence use of credit.

\section{Statement of no competing interests}

We, the authors hereby declare that there are no competing interest in this research and publication.

\section{Acknowledgements}

This study was largely self-funded by the team of researcher from both Jomo Kenyatta University of Agriculture and Technology (JKUAT). However, the authors greatly acknowledge the support from the institutions for availing ample time to complete this research. The authors are very grateful to the local authorities and the farmers in Gisagara District for good collaboration.

\section{References}

[1] Ali, D. A., Deininger, K., and Duponchel, M. (2014). Credit constraints and agricultural productivity: evidence from rural Rwanda. Journal of Development Studies, 50(5), 649665

[2] Apata, T., Apata, O., Igbalajobi, O., and Awoniyi, S. (2010). Determinants of rural poverty in Nigeria: Evidence from small holder farmers in South-western, Nigeria. International Journal of Science and Technology Education Research, 1(4), 85-91

[3] Bhattacharjee, M., and Rajeev, M. (2010). Interest rate formation in informal credit markets in India:does level of development matter? Brooks World Poverty Institute Working Paper, 126

[4] Girma, M., and Abebaw, D. (2015). Determinants of Formal Credit Market Participation by Rural Farm Households: Micro-level evidence from Ethiopia. Paper presented at the Paper for presentation at the 13 th International Conference on the Ethiopian Economy. Ethiopian Economic Association (EEA) Conference Centre, Addis Ababa, Ethiopia

[5] Imbens, G. W., and Wooldridge, J. M. (2009). Recent developments in the econometrics of program evaluation. Journal of economic literature, 47(1), 5-86

[6] Mijena, A. (2011). Determinants of credit repayment and fertilizer use by cooperative members in Ada District, East Shoa Zone, Oromia Region. Haramaya University

[7] Mutandwa, E., Kanuma, N. T., Rusatira, E., Kwiringirimana, T., Mugenzi, P., Govere, I., and Foti, R. (2009). Analysis of coffee export marketing in Rwanda: Application of the Boston consulting group matrix. African Journal of Business Management, 3(5), 210

[8] Wiggins, S. (2009). Can the smallholder model deliver poverty reduction and food security

[9] Yehuala, S. (2008). Determinants of smallholder farmers access to formal credit: 
the case of Metema Woreda, North Gondar, Ethiopia. Haramaya University

[10] Ahmad Adel Jamil AbdAlla. (2013). The Impact of Internal Control to E-commerce Activities on the Quality of Internal Auditing in the Financing Companies Operating in Jordan
[11] NISR. (2016). Seasonal Agricultural Survey. Kigali: Nationational Institute of Statistics of Rwanda.

[12] Sulaiman M. (2015). Profitability of Sugarcane Production and Its Contribution to Farm Income of Farmers in Kaduna State. Nigeria. 